\title{
THE FOUR MAJOR FORMS OF BARLEY B-AMYLASE. PURIFICATION, CHARACTERIZATION AND STRUCTURAL RELATIONSHIP
}

by

\author{
ROBERT LUNDGARD and BIRTE SVENSSON
}

\author{
Department of Chemistry, Carlsberg Laboratory, \\ Gamle Carlsberg Vej 10, DK-2500 Copenhagen Valby
}

Keywords: Limited proteolysis, $\mathrm{COOH}$-terminal sequence, $\mathrm{NH}_{2}$-terminal
N-acetyl-methionine, barley proteases

Four major forms of barley $\beta$-amylase have been purified in the presence of $0.1 \mathrm{M}$-thiol from extracts of flour fractionated by ammonium sulfate precipitation and chromatography on DEAE-cellulose and DEAE-Fractogel. The $\beta$-amylases were $\mathrm{NH}_{2}$-terminally blocked, single polypeptide chains of approx. $\mathrm{M}_{\mathrm{r}} 59,700,58,000,56,000$ and 54,000 , with corresponding pI 5.2, 5.3, 5.5 and 5.7. All forms displayed optimal activity on soluble starch between $\mathrm{pH} 4.5$ and 7.5 ; all $\mathrm{K}_{\mathrm{m}}$ and $\mathrm{V}_{\text {max }}$ values were $2.5 \mathrm{mg} \cdot \mathrm{ml}^{-1}$ and $17 \mu$ mol maltose $\cdot \mathrm{min}^{-1}$. (nmol protein) ${ }^{-1}$, respectively.

The $\beta$-amylase 4 consisted of different components terminating between Gly 493 and GIn 497 in the amino acid sequence deduced from the nucleotide sequence of a full length cDNA (KREIS et al., Eur. J. Biochem., in press (1987)). $\beta$-Amylase 4 is the main product from limited proteolysis of the large form, $\beta$-amylase 1 , catalysed by malt protease(s), papain or subtilisin. Intermediate forms of $\beta$-amylase with $\mathrm{pI} 5.3$ and 5.5 were generated with crude malt enzymes, $\alpha$-chymotrypsin or thermolysin. The conversion effected by malt enzymes was prevented by leupeptin and EDTA in combination.

\section{INTRODUCTION}

$\beta$-Amylase ( $\alpha$-1,4-glucan maltohydrolase; EC 3.2.1.2) catalyses the liberation of $\beta$-maltose from the nonreducing ends of starch and related 1,4- $\alpha$-glucans (47). Native or damaged starch granules are not hydrolysed by $\beta$-amylase $(9,36$, $54)$, but in the presence of $\alpha$-amylase a synergistic degradation of barley starch granules takes place (36).

$\beta$-Amylase occurs in higher plants, most notably in barley, wheat, soybean and sweet potato (47). In cereal grains it is concentrated in the sub-aleurone layer of the starchy endosperm $(32,33)$ where it is deposited on starch granules as a latent enzyme $(3,6)$ during the desiccation phase of seed development (18); small amounts may occur also in the scutellum (32). A $\beta$-amylase in germinating rice is synthesized de novo in addition to the dominant form stored in the starchy endosperm (44). Cereal $\beta$-amylase exists in "free" and "bound" forms. "Free" enzyme is extracted from flour with aqueous salt solutions while "bound" enzyme, attached to proteins via disulfide linkage(s) $(18,19,48)$ is released by

Abbreviations: DFP = diisopropylfluorophosphate; DTNB = 5,5'-dithiobis(2-nitrobenzoic acid); EDTA = ethylenediaminetetraacetic acid; $\mathrm{p}$-CMB $=$ p-chloromercuribenzoic acid; $\mathrm{pI}=$ isoelectric point; $\mathrm{PMSF}=$ phenylmethanesulfonyl fluoride; $\mathrm{PTH}=$ phenylthiohydantoin; RP-HPLC $=$ reverse-phase high performance liquid chromatography; SDS = sodium dodecyl sulfate; SDS-PAGE = SDS-polyacrylamide gel electrophoresis; TFA = trifluoroacetic acid; Tris $=2$-amino-2(hydroxymethyl)-1,3-propandiol. 
re-extraction with buffers containing thiol or papain.

The literature contains numerous investigations dealing with the polymorphism of plant $\beta$-amylases. Ion exchange chromatography, isoelectric focusing and chromatofocusing thus revealed variable numbers of multiple forms $(28,30,31,40)$ and a size range from $M_{r} 40,000$ to $400,000(2,42,43)$ has been demonstrated by gel filtration, SDS-PAGE and ultracentrifugation. Monomeric forms from barley were immunochemically identical, charge heterogeneous single polypeptide chains of $\mathrm{M}_{\mathrm{r}} \sim 60,000$ (53). There are basically two reasons for the multiplicity of forms of barley $\beta$-amylase: one is proteolytic conversion(s) giving rise to charge and size differences $(3,26,29,34)$, the other is the presence of thiol groups which can participate in intermolecular disulfide formation (3, $43,53)$, thiol disulfide interchange (29) and association with other proteins, like the $\mathrm{Z}$ protein, yielding heterodimers $(19,20)$. A comprehensive scheme describing possible origins of multiple forms of cereal $\beta$-amylase has been presented by BRIGGS (3). VISURI and NUMMI (53) purified a mixture of barley $\beta$-amylase forms in the presence of high thiol concentrations and reported chemical and analytical data for four monomeric forms in the mixture. We now describe the isolation and chemical and enzymatic properties of each of the four major naturally occurring monomeric forms of barley $\beta$-amylase. Recently, the amino acid sequence deduced from the nucleotide sequence of a full length cDNA clone for barley $\beta$-amylase has been determined by KREIS et al. (25), and we have shown that limited proteolysis in the $\mathrm{COOH}$-terminal region of the larger form, barley $\beta$-amylase 1 , generated another major form (34). In the present study it is found that the formation of multiple forms through limited proteolysis by exogenous and endogenous proteases can be correlated with the primary structure of the $\mathrm{COOH}$-terminal region.

\section{MATERIALS AND METHODS}

\subsection{Materials}

Barley seeds (Hordeum vulgare L., cv. Gula) were from the Carlsberg research Farm 1985 harvest. Green malt (cv. Havila, germinated $5 \mathrm{~d}$, $15{ }^{\circ} \mathrm{C}$ ), obtained from the Carlsberg Malting Plant, Copenhagen, was used as a source of endogenous proteases.

Ampholine PAG-plates, $\mathrm{pH}$ 4-6.5 were from LKB, Bromma, Sweden. Low molecular weight protein markers and low pI kit were from Pharmacia, Uppsala, Sweden. Sigma, St. Louis, MO, supplied soluble potato starch (Lintner method), pepstatin A, DFP, iodoacetamide, pCMB, papain, $\alpha$-chymotrypsin, pepsin, collagenase from Clostridium histolyticum, and Azocoll. Subtilisin A was from Novo Industries, Copenhagen, Denmark, Staphylococcus aureus V8 protease from Miles Laboratories, Naperville, IL, thermolysin from Daiwa Kasei, Osaka, Japan, yeast acid protease (7) was kindly provided by T. DREYER and barley malt carboxypeptidase II (4) by K. BREDDAM, both this laboratory. Leupeptin was from Bachem AG, Bubendorf, Switzerland. $\beta$-Limit dextrin from POS Pilot Plant Corp., Saskatoon, Canada, and DTNB from Merck, Darmstadt, F.R.G. Purified $\alpha$ amylase 1 and $2(12,49)$ were supplied by R.M. GiBSON, this laboratory. Barley starch granules were a gift from B.S. ENEvoldSEN, Department of Brewing Chemistry, Carlsberg Research Laboratory. Other materials used were mentioned previously (34).

\subsection{Methods}

\subsubsection{Extraction and purification of $\beta$-amylases 1 to 4}

Monothioglycerol $(0.1 \mathrm{M})$ was present throughout the isolation procedure. Protein extracted from barley flour $(10 \mathrm{~kg})$ was initially fractionated as described (34) by $\left(\mathrm{NH}_{4}\right)_{2} \mathrm{SO}_{4}$ precipitation. The proteins were redissolved, dialysed against $15 \mathrm{mM}$-Tris- $\mathrm{HCl} \mathrm{pH} 7.0$ and colored material was removed on a DEAE-cellulose column $(10 \times 14 \mathrm{~cm})$ in the same buffer. All $\beta$-amylase activity was in the pass-through and this solution was adjusted to $\mathrm{pH} 8.0$, applied to DEAE-cellulose DE-52 $(10 \times 23 \mathrm{~cm})$ equilibrated in $15 \mathrm{~mm}$ Tris- $\mathrm{HCl} \mathrm{pH} 8.0$ and eluted by a gradient from zero to $0.15 \mathrm{M}-\mathrm{NaCl}$ at a flow rate of $220 \mathrm{ml} \cdot \mathrm{h}^{-1}$. Peaks of $\beta$-amylase activity eluting between 0.04 $\mathrm{M}$ and $0.06 \mathrm{M}-\mathrm{NaCl}$ were pooled separately, dialysed against $15 \mathrm{~mm}$-Tris- $\mathrm{HCl} \mathrm{pH} 8.0$ and 
portions (100-200 $\mathrm{mg}$ of protein) were chromatographed on Fractogel TSK DEAE-650(S) $(2.5 \times 50 \mathrm{~cm})$ in the above buffer using a 2.21 linear gradient from zero to $0.075 \mathrm{M}-\mathrm{NaCl}$. The resulting peaks of $\beta$-amylase activity were pooled separately and each rechromatographed in the same system. Selected fractions were subjected to analytical isoelectric focusing and fractions containing charge homogeneous $\beta$ amylase components were pooled, concentrated in an Amicon ultrafiltration cell (YM 30 filter), and dialysed against $10 \mathrm{~mm}$-sodium acetate, $\mathrm{pH}$ 5.0 containing $2 \mathrm{~mm}$-DTT. The obtained solutions of homogeneous $\beta$-amylases 1 to 4 (2-6 $\mathrm{mg} \cdot \mathrm{ml}^{-1}$ ) were flushed briefly with nitrogen. They could be stored at $-18{ }^{\circ} \mathrm{C}$ without loss of activity or conversion to other forms. Omission of $\mathrm{N}_{2}$ flushing and DTT prior to freezing promoted precipitation and inactivation of the protein.

\subsubsection{Assay of $\beta$-amylase activity}

$\beta$-Amylase activity was assayed with soluble starch. Typically $0.05-1 \mu \mathrm{g} \beta$-amylase in 10 mM-sodium acetate $\mathrm{pH} 5.5$ containing $4 \mathrm{~mm}$ dithiothreitol $(50 \mu \mathrm{l})$ was incubated at $21^{\circ} \mathrm{C}$ with $0.8 \%$ soluble starch in $50 \mathrm{~mm}$-sodium acetate at pH $5.5(1 \mathrm{ml})$. After a reaction time of 1 to 20 min, chosen to ensure linearity, the liberated maltose was analyzed with the Nelson alkaline copper reagents (46). The $\mathrm{pH}$ optimum for the activity was determined with starch dissolved in 25 mM-citrate-phosphate buffers pH 3-9 (13) prior to addition of enzyme $(1 \mu \mathrm{g})$. These buffers had no influence on the maltose analysis. The $\mathrm{K}_{\mathrm{m}}$ and $\mathrm{V}_{\text {max }}$ were determined from LineweaverBurk plots of initial rates of hydrolysis at $21{ }^{\circ} \mathrm{C}$ of soluble starch (0.05-1.5\%) in 50 mM-sodium acetate buffer $\mathrm{pH}$ 5.5. The possible presence of $\alpha$-amylase activity was examined by incubating $40 \mu \mathrm{g}$ of each of the purified $\beta$-amylases with $\beta$-limit dextrin ( $2 \%$ in $50 \mathrm{~mm}$-acetate, $1 \mathrm{~mm}$-Ca-

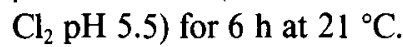

\subsubsection{Gel electrophoresis and isoelectric focusing}

Slab SDS-PAGE was performed in $1 \mathrm{~mm} \mathrm{10 \%}$ separating gels with 5\% stacking gels (27).
Protein was stained with Coomassie brilliant blue or silver (57) and $\mathrm{M}_{\mathrm{r}}$ was estimated according to WEBER et al. (55). Analytical isoelectric focusing gels ( $\mathrm{pH} 4-6.5$ ) were used according to the manufacturers' instructions (56) and protein and $\beta$-amylase activity was visualized as previously described (34).

\subsubsection{Amino acid composition and chemical characterization}

Amino acid analysis was performed with a Durrum D-500 amino acid analyzer. The protein samples $(50 \mu \mathrm{g})$ were hydrolyzed in sealed, evacuated tubes with $6 \mathrm{~N}-\mathrm{HCl}$ for 24,48 , and $72 \mathrm{~h}$ at $110^{\circ} \mathrm{C}$. Tryptophan was estimated spectrophotometrically by the method of GooDWIN and MORTON (14). Half-cystine content was determined as cysteic acid after performic acid oxidation (22). Contents of free sulfhydryl groups in native and SDS-denatured enzyme were measured with DTNB (16). Native enzyme was dialysed overnight in degassed and $\mathrm{N}_{2}$ flushed 2 mm-acetate $\mathrm{pH} 5.5$ containing 0.2 mM-dithiothreitol and $10 \mathrm{~mm}-\mathrm{DTNB}(50 \mu \mathrm{l})$ was added to the native enzyme $(7 \mu \mathrm{M})$ or a blank containing the same dialysis buffer in $0.1 \mathrm{M}$ sodium phosphate, $\mathrm{pH} 8(1 \mathrm{ml})$. The concentration of thiol was calculated at various times after mixing from the absorption at $412 \mathrm{~nm}$ by use of $\varepsilon=13,600 \mathrm{M}^{-1} \cdot \mathrm{cm}^{-1}(16)$.

Amino acid sequencing and identification of PTH-amino acids were performed on Applied Biosystems model 470A gas-phase sequencer and model 120A PTH analyzer according to the manufacturers' instructions.

Neutral carbohydrate was analysed by the phenol sulfuric acid method (8) on $4 \mathrm{mg}$ of protein with mannose as a standard.

$\beta$-Amylase concentration was determined either from amino acid analysis or spectrophotometrically using $\varepsilon_{280}=9.4 \cdot 10^{4} \mathrm{M}^{-1} \cdot \mathrm{cm}^{-1}$ which had been calculated from protein content determined by amino acid analysis and absorbance at $280 \mathrm{~nm}$ of solutions of $\beta$-amylases 1 to 4 . Electron impact mass spectrometry was carried out on a Finnigan MAT 311 mass spectrometer operated at $70 \mathrm{eV}$ electron energy and a resolution of 1000 . The sample was introduced without further derivatization using the direct inlet system. 


\subsubsection{Preparation and separation of $\mathrm{CNBr}$ fragments}

Purified and lyophilized $\beta$-amylase $4(10 \mathrm{mg}$ ) was cleaved with $\mathrm{CNBr}$ and the mixture of resulting fragments fractionated on Bio-Gel $\mathrm{P}$ 100 as described (25). Pools of medium and short length fragments were subjected to RPHPLC using a Baker Wide-Pore C18 (RKP $7104)$ column $(4.6 \times 250 \mathrm{~mm})$ with elution by a gradient of $2-55 \%$ acetonitrile in $0.1 \%$ TFA over $90 \mathrm{~min}$ at a flow rate of $0.5 \mathrm{ml} \cdot \mathrm{min}^{-1}(50)$. Peptides were monitored at $220 \mathrm{~nm}$. Selected peaks were rechromatographed on the same system using a narrow gradient range.

\subsubsection{Limited proteolysis}

$\beta$-Amylase $1\left(0.5 \mathrm{mg} \cdot \mathrm{ml}^{-1}\right)$ was treated with exogenous proteases at a molar ratio of 1:50 near the $\mathrm{pH}$ optimum for each protease. Incubation with trypsin, subtilisin, $\alpha$-chymotrypsin and thermolysin was at $\mathrm{pH} 8.0$ in 20 mM-Tris- $\mathrm{HCl}$. Treatment with papain and malt carboxypeptidase II was in 20 mm-sodium acetate pH 5.5 while collagenase, pepsin, and yeast acid protease were used in citrate buffer at both $\mathrm{pH}$ 2.8 and 3.5 . For $a$-chymotrypsin, collagenase and thermolysin $1 \mathrm{~mm}$-CaCl was included in the buffer and for thermolysin also $1 \mathrm{mM}-\mathrm{ZnCl}_{2}$ was added. The mixtures $(0.2 \mathrm{ml})$, containing 2 mM-DTT to stabilize $\beta$-amylase and $0.02 \%$ $\mathrm{NaN}_{3}$ to inhibit microbial growth, were incubated overnight at $21^{\circ} \mathrm{C}$ followed by application (20 $\mu \mathrm{l})$ either directly to analytical isoelectric focusing gels (for protein stain) or diluted 100-fold in water (for activity stain) (section 2.2.3). In cases of partial or no conversion of $\beta$-amylase 1 , the protease to $\beta$-amylase ratio was increased to $1: 5$ followed by reincubation overnight $\left(21^{\circ} \mathrm{C}\right)$ and isoelectric focusing.

Endogenous malt proteases were extracted by grinding $2 \mathrm{~g}$ of green malt in $4 \mathrm{ml} 2 \mathrm{~mm}$-sodium acetate, $\mathrm{pH} 5.0$ containing $2 \mathrm{~mm}$-DTT. The supernatant of the centrifuged $(10,000 \times \mathrm{g}, 10$ min) homogenate (stored at $-18^{\circ} \mathrm{C}$ ) was used as source of proteases and showed activity towards Azocoll (5). For limited proteolysis $\beta$-amylase 1 $(50-100 \mu \mathrm{g})$ was mixed with the malt extract (50 $\mu \mathrm{l}$ ) in $20 \mathrm{~mm}$-acetate, $\mathrm{pH} 4.5$ (or $20 \mathrm{~mm}$-Tris, $\mathrm{pH}$ $8.0)$ as described above. In parallel experiments malt extract was incubated $\left(1 \mathrm{~h}, 21^{\circ} \mathrm{C}\right)$ prior to addition of $\beta$-amylase 1 with protease inhibitors or with either $10 \mathrm{mM}$-DTNB or $10 \mathrm{mM}$-iodoacetamide in $10 \mathrm{~mm}$-sodium phosphate, $\mathrm{pH} 8.0$ (overnight, $21^{\circ} \mathrm{C}$ ) followed by dialysis against 2 mM-acetate, pH 5.0 (37).

\subsubsection{Adsorption to starch granules}

Amylase adsorption to starch granules was performed essentially as previously published (35). Predigested granules were made by incubation with purified barley $\alpha$-amylase 1 and 2 followed by washing and drying (9). Dried starch granules $(25 \mathrm{mg})$ were mixed with $100 \mu \mathrm{g}$ of

Table I. Purification of barley $\beta$-amylases 1 to 4

\begin{tabular}{|c|c|c|c|c|}
\hline & $\begin{array}{l}\text { Protein } \\
\text { (g) }\end{array}$ & $\begin{array}{l}\text { Total activity } \\
\left(\text { mmol maltose } \cdot \mathrm{min}^{-1}\right)\end{array}$ & $\begin{array}{l}\text { Specific } \\
\text { activity }\end{array}$ & $\begin{array}{l}\text { Yield } \\
(\%)\end{array}$ \\
\hline Initial extract & 126 & 2,500 & 20 & 100 \\
\hline $\begin{array}{l}20-60 \% \text { satd., } \\
\left(\mathrm{NH}_{4}\right)_{2} \mathrm{SO}_{4} \text {-ppte }\end{array}$ & 14.7 & 1,940 & 132 & 77 \\
\hline DEAE-Cellulose (pH 7.0) & 12.0 & 1,940 & 160 & 77 \\
\hline DEAE-Cellulose (pH 8.0) & 7.6 & 1,750 & 230 & 70 \\
\hline DEAE-Fractogel 4 & 0.45 & 144 & 320 & 5.7 \\
\hline DEAE-Fractogel 3 & 0.14 & 41.7 & 298 & 1.6 \\
\hline DEAE-Fractogel 2 & 0.34 & 100 & 294 & 4.0 \\
\hline DEAE-Fractogel 1 & 0.65 & 178 & 274 & 7.0 \\
\hline Sum of $\beta$-amylases 1 to 4 & 1.58 & 464 & 296 & 18 \\
\hline
\end{tabular}




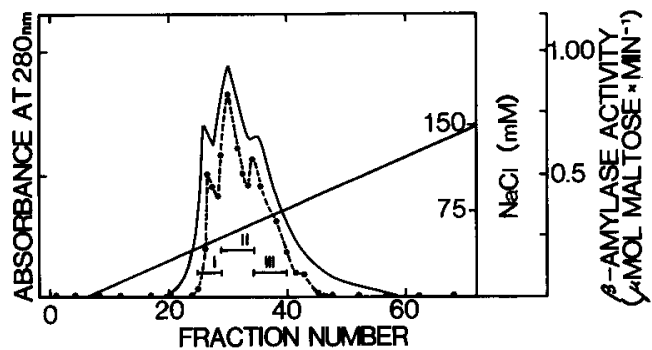

Figure 1. Chromatography of barley $\beta$-amylase from $20-60 \%\left(\mathrm{NH}_{4}\right)_{2} \mathrm{SO}_{4}$ precipitation of flour extract on DEAE-cellulose at $\mathrm{pH} 8.0$ (see section 2.2.1). The eluate was monitored at $280 \mathrm{~nm}$ (solid line) and the $\beta$-amylase activity (---) measured with starch as substrate (see section 2.2.2). The activity values shown are from $50 \mu \mathrm{l}$ of a 100 -fold dilution of the eluted fractions $(275 \mathrm{ml})$. The three peaks of $\beta$-amylase activity were pooled as indicated by bars and rechromatographed on DEAE-Fractogel.

$\beta$-amylase, or $50 \mu \mathrm{g}$ each of $\alpha$-amylase 1 and 2 in $4 \mathrm{ml} 50 \mathrm{~mm}$-acetate, $\mathrm{pH} 5.5$ containing 1 mM-DTT (replaced with $1 \mathrm{~mm}-\mathrm{CaCl}_{2}$ for $\alpha$-amylase) and gently shaken for $2 \mathrm{~h}$ at $5{ }^{\circ} \mathrm{C}$. The extent of adsorption was determined by comparing the amylase activity in the supernatant with that in controls lacking starch.

\section{RESULTS}

\subsection{Purification and physical and chemical characterization of multiple forms of barley $\beta$-amylases}

The purification of the four major forms of $\beta$-amylase from $10 \mathrm{~kg}$ of barley flour is outlined in Table I. After aqueous extraction in $0.1 \mathrm{M}$-thiol and fractionation in 20 to $60 \%$ $\left(\mathrm{NH}_{4}\right)_{2} \mathrm{SO}_{4}$ colored material was removed and pools I-III, containing $\beta$-amylase, were isolated (see 2.2.1) by DEAE-cellulose chromatography (Figure 1) and separately purified on DEAEFractogel. Corresponding peaks from the three different DEAE-Fractogel separations (shown in Figure 2 only for pool II from DEAE-cellulose chromatography) were combined and rechro-

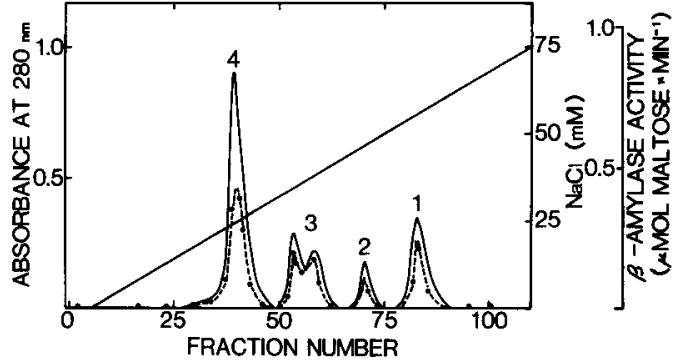

Figure 2. Separation of the four major forms of barley $\beta$-amylase on DEAE-Fractogel. A portion (100 mg) of pool II from the DE-52 column (Figure 1) was rechromatographed on a DEAE-Fractogel (see section 2.2.1). Eluate was monitored at $280 \mathrm{~nm}$ (solid line) and $\beta$-amylase activity (---) in the fractions $(20 \mathrm{ml})$ was measured as described in Figure 1. The peaks of activity corresponding to the four forms (number above peaks) were pooled separately and rechromatographed using the same column and gradient conditions.

matographed. Conspicuous shoulders were often observed and found to contain protein with the same isoelectric point as in the respective adjacent main peaks. Variation in relative amounts of the $\beta$-amylase forms was seen from different preparations.

The isolated $\beta$-amylases migrated in SDSPAGE as single bands corresponding to $\mathrm{M}_{\mathrm{r}}$ ranging from 59,700 for $\beta$-amylase 1 to 54,000 for $\beta$-amylase 4 (Figure 3 ). Analytical isoelectric focusing revealed that $\beta$-amylases 1 to 4 had approximate $\mathrm{pI}$ of 5.2, 5.3, 5.5 and 5.7 (Figure 4). Two close protein bands, $3^{1}$ and $3^{2}$, of $\beta$-amylase $3(\mathrm{pI} \sim 5.5)$ (Figure 4 ) are consistent with the split peak observed for that form on DEAE-Fractogel (Figure 2). Form $3^{1}$ has the lower $\mathrm{pI}$ and it is slightly smaller than $3^{2}$ (data not shown).

$\beta$-Amylase 1 predominated in the crude extract (Figure 4A, lane 1) while the amount of $\beta$-amylase 4 increased during purification indicating degradation to occur. It has previously $(29,30)$ been reported that $\beta$-amylase(s) of higher isoelectric point (presumably $\beta$-amylase 4) appear when proteolytic activity increases in malt $(10,39)$. 


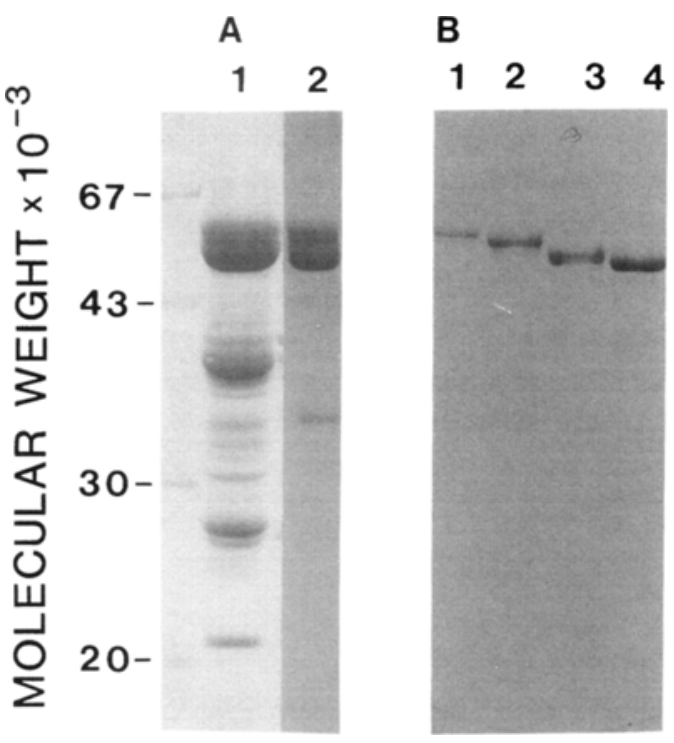

Figure 3. Molecular weight estimation of purified $\beta$-amylases 1 to 4 following reduction and denaturation (see section 2.2.3).

A. Coomassie protein stain of $20-60 \%$ satd. $\left(\mathrm{NH}_{4}\right)_{2} \mathrm{SO}_{4}$ fractionation of crude extract (lane 1) and $\beta$-amylase $(20 \mu \mathrm{g})$ purified by DEAE-cellulose chromatography (peak II, Figure 1) (lane 2).

B. Silver protein stain of $\beta$-amylases 1 to $4(-5 \mu \mathrm{g}$ each; lanes 1 to 4 ) obtained by subsequent separation of material in A, lane 2 on DEAE-Fractogel.

The amino acid compositions of $\beta$-amylases 1 to 4 (Table II) resemble results reported by VISURI and Nummi (53) for a mixture of barley $\beta$-amylase forms. Furthermore, the composition of $\beta$-amylase 1 , the largest form, is in excellent agreement with that derived from the nucleotide sequence of a full-length barley $\beta$ amylase cDNA clone (25). No neutral carbohydrate was detected in any of the forms and they were all $\mathrm{NH}_{2}$-terminally blocked (see section 3.3) as indicated by the lack of release of PTHamino acids in automated Edman degradation (see section 2.2.4).

\subsection{Enzymic properties}

Incubation of the purified $\beta$-amylase forms with $\beta$-limit dextrin did not liberate reducing sugar (see section 2.2.2) confirming the absence of $\alpha$-amylase activity.

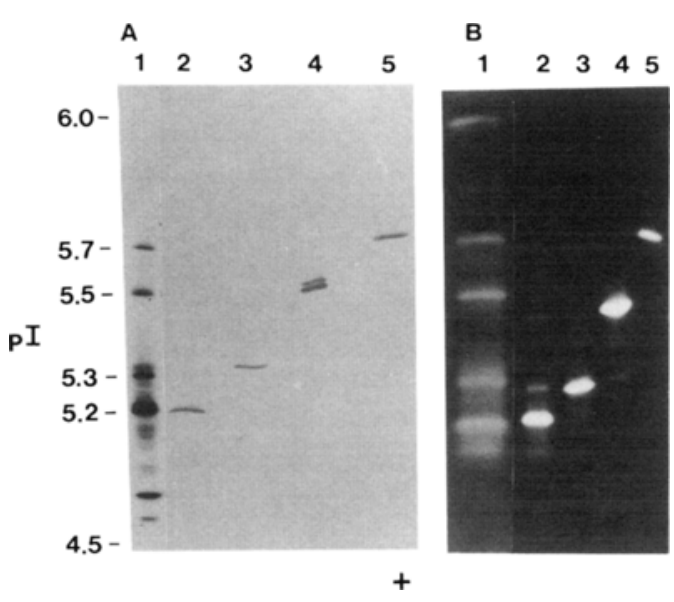

Figure 4. Analytical isoelectric focusing of $\beta$-amylases 1 to 4 (see section 2.2.3). The approximate $\mathrm{pI}$ values of the individual forms are indicated.

A. Crude extract after concentration by ultrafiltration $(-50 \mu \mathrm{g}$; lane 1$)$; homogeneous $\beta$-amylases 1 to $4(-8$ $\mu \mathrm{g}$ each; lanes 2 to 5) (Coomassie protein stain).

B. Same samples $(\sim 0.1 \mu \mathrm{g})$ as in A stained for activity (starch $\mathrm{I}_{2} / \mathrm{KI}$ ).

The very similar $\mathrm{pH}$ activity profiles of the four $\beta$-amylases show a broad optimum from about $\mathrm{pH} 4.0$ to 7.5 (Figure 5) which is consistent with other $\beta$-amylase preparations $(1,51)$. All of the four forms had $\mathrm{K}_{\mathrm{m}}$ for hydrolysis of soluble starch of $2.5 \pm 0.3 \mathrm{mg} \cdot \mathrm{ml}^{-1}$ with corresponding $\mathrm{V}_{\max }$ values of $17 \pm 2 \mu \mathrm{mol} \mathrm{mal-}$ tose $\cdot \min ^{-1} \cdot(\text { nmol protein })^{-1}$ (see section 2.2 .2 ).

The correlation between loss of enzyme activity and the number of sulfhydryl groups modified by DTNB in the native enzyme is shown in Figure 6. Modification of 1 or 2 cysteines gave a small but significant activation which was followed by rapid inactivation resulting from loss of 3 to 5 sulfhydryl groups. The half-cystine content (Table II) and the sulfhydryl content of $6.2,6.0,5.5$ and $5.0 \pm 0.2$ after SDS-denaturation of $\beta$-amylases $1,2,3$ and 4 , respectively, indicate that $\beta$-amylase has no disulfide bridges. Analysis before and after denaturation suggest that 2 sulfhydryl groups are buried in barley $\beta$-amylase similarly to the soybean enzyme ( 38 , $40)$. 
R. LUNDGARD \& B. SVENSSON: Multiple forms of $\beta$-amylase

Table II. Amino acid compositions of barley $\beta$-amylases 1 to 4

\begin{tabular}{|c|c|c|c|c|c|}
\hline Form of enzyme & 1 & 2 & 3 & 4 & $\mathrm{cDNA}^{\mathrm{f}}$ \\
\hline & \multicolumn{5}{|c|}{ (Residues per molecule) } \\
\hline Aspartic acid & 56 & 55 & 55 & 53 & 57 \\
\hline Threonine $^{\text {a) }}$ & 21 & 20 & 17 & 16 & 21 \\
\hline Serine ${ }^{\text {a) }}$ & 25 & 23 & 23 & 22 & 22 \\
\hline Glutamic acid & 60 & 58 & 55 & 51 & 59 \\
\hline Proline & 35 & 34 & 34 & 32 & 36 \\
\hline Glycine & 53 & 50 & 43 & 42 & 56 \\
\hline Alanine & 44 & 44 & 40 & 38 & 41 \\
\hline Valine ${ }^{\text {b) }}$ & 37 & 37 & 34 & 34 & 37 \\
\hline Methionine & 17 & 16 & 15 & 14 & 18 \\
\hline Isoleucine $^{b)}$ & 21 & 22 & 21 & 19 & 22 \\
\hline Leucine & 42 & 40 & 39 & 38 & 41 \\
\hline Tyrosine & 23 & 22 & 23 & 23 & 24 \\
\hline Phenylalanine & 23 & 22 & 22 & 21 & 23 \\
\hline Histidine & 13 & 12 & 12 & 13 & 14 \\
\hline Lysine & 24 & 25 & 22 & 21 & 22 \\
\hline Arginine & 27 & 27 & 27 & 27 & 27 \\
\hline Half-cystine ${ }^{c)}$ & 6 & 6 & 5 & 5 & 5 \\
\hline Tryptophan d) & 10 & 10 & 10 & 10 & 10 \\
\hline Approx. $M_{r}{ }^{e)}$ & 59,700 & 58,000 & 56,000 & 54,000 & $59,660^{\mathrm{B})}$ \\
\hline
\end{tabular}

The values are based on the $M_{5}$, and represent an average of duplicate amino acid analyses after hydrolysis in 6 $\mathrm{N}-\mathrm{HCl}$ for 24,48 , and $72 \mathrm{~h}$.

a) Extrapolated to zero-time of hydrolysis.

b) Value from $72 \mathrm{~h}$ hydrolysis.

c) Determined as cysteic acid after performic acid oxidation and by quantitation with DTNB (section 2.2.4).

d) Spectrophotometrically determined (14).

e) Determined by SDS-PAGE (see 2.2.3).

f) From Kreis et al. (25).

g) Calculated from the amino acid composition.

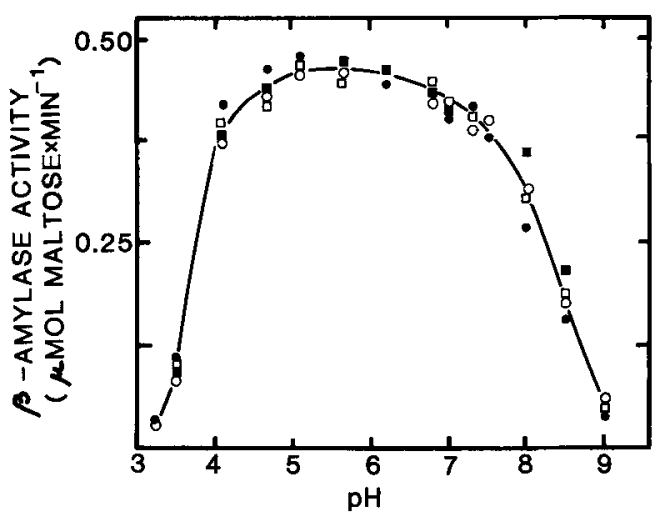

Figure 5 . The effect of $\mathrm{pH}$ on the activity of $\beta$-amylases 1-4. $\beta$-amylase $1, \propto ; \beta$-amylase 2,$0 ; \beta$-amylase 3 , $\square ; \beta$-amylase $4, \square$. Data are from enzyme assays $(50 \mu \mathrm{l}$ incubated 1-5 $\mathrm{min}$ ) in citrate-phosphate buffers (see section 2.2.2).

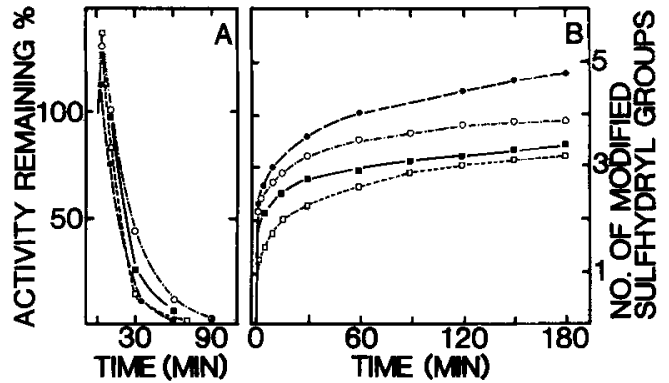

Figure 6. Determination of free sulfhydryl groups with DTNB in native $\beta$-amylases 1 to 4 (section 2.2.4). A. The remaining enzyme activity. B. The number of modified sulfhydryl groups. Both were measured as a function of time. $\beta$-amylases 1 to 4 , respectively: -- - -; --O--; --口--; -- $\square-$. 
R. LUNDGARD \& B. SVENSSON: Multiple forms of $\beta$-amylase

470

480

Met-Il e-Leu-Gln-Ala-Al a-Gln-Pro-Lys-Leu-Gln-Pro-Phe-Pro-Phe-Gln-Glu-Hi s-Thr-Asp-Leu-Pro-Val-Gly-

$490 \quad$ A $\quad$ B $\quad C \quad$ D $\quad 500 \quad 510$

Pro-Thr-Gly Gly-Met-Gly-Gly-Gln-Al a-Glu-Gly-Pro-Thr-Cys-Gly-Met-Gly-Gly-Gln-Val-Lys-Gly-Pro-Thr$\Theta$ $(\oplus$

520 530

Gly-Gly-Met-Gly-Gly-GIn-Al a-Glu-Asp-Pro-Thr-Ser-Gly-Met-Gly-Gly-Glu-Leu-Pro-Ala-Thr-Met-COOH $\Theta \Theta$

$\Theta$

Figure 7. Amino acid sequence of the $\mathrm{COOH}$-terminal region of barley $\beta$-amylase deduced from the corresponding cDNA (25) with the exception of Met527 which was determined by peptide sequencing of Gly511-Ala533 (34) but suggested to be Ile from the cDNA sequence (25).

The $\mathrm{COOH}$-terminal residues identified in various $\mathrm{COOH}$-terminal $\mathrm{CNBr}$-fragments from $\beta$-amylase 4 are indicated by A, B, C, D (see 3.3, Table III and Figure 8). Charged residues are indicated in the region containing the repeat-sequences (boxed) that are suggested as protease targets. A segment of $\beta$-amylase 1 removed by trypsin (34) extends from Gly511 to Ala533.

\section{3. $\mathrm{COOH}$-termini and $\mathrm{NH}_{2}$-terminus of} B-amylase 4

$\beta$-Amylase 4 seems to be a main product of the conversion of $\beta$-amylase by limited proteolysis. In order to determine its $\mathrm{COOH}$-terminal residue(s) $\mathrm{CNBr}$-fragments were made and char- acterized (see 2.2.5 and ref. 25). No fragments were observed containing residues from the stretch from Ala498 to Met535, a region where a segment was removed from $\beta$-amylase 1 by limited proteolysis with trypsin (34) (see Figure 7). A pool containing $\mathrm{CNBr}$-fragments having

Table III. Amino acid composition of peptides generated by $\mathrm{CNBr}$ cleavage in the COOH-terminal region of B-amylase 4.

\begin{tabular}{llllc}
\hline Peptide & A & B & C & D \\
\hline & & \multicolumn{2}{l}{ (Residues per fragment) } \\
Aspartic acid & 1.2 & 1.0 & 1.2 & 1.1 \\
Threonine & 1.7 & 2.0 & 1.8 & 2.0 \\
Glutamic acid & 4.7 & $5.5^{\text {a) }}$ & 4.9 & 5.6 \\
Proline & 3.9 & 4.9 & 4.1 & 4.1 \\
Glycine & 2.9 & 3.1 & 3.7 & 4.8 \\
Alanine & 1.7 & 2.2 & 1.9 & 2.0 \\
Valine & 0.6 & 0.9 & 0.6 & 0.9 \\
Methionine & 0 & 0 & 0.4 & 0.6 \\
Isoleucine & 0.9 & 0.9 & 0.9 & 1.0 \\
Leucine & 2.7 & 3.1 & 2.7 & 2.7 \\
Phenylalanine & 1.7 & 2.0 & 1.7 & 1.8 \\
Histidine & 1.1 & 1.0 & 1.0 & 1.0 \\
Lysine & 1.1 & 1.0 & 0.9 & 1.1 \\
Homoserine lactone & $<0.2$ & 0.6 & $<0.2$ & $<0.1$ \\
Sequenceb) & I467-G493 & I467-Hse/Hsl494 & I467-G495 & I467-Q497 \\
Elution position ${ }^{\text {c) }}$ & 34.0 & 33.3 & 32.7 & 32.4 \\
\hline
\end{tabular}

The elution positions in RP-HPLC of peptides A-D are shown in Figure 8.

a) Contribution from homoserine included in the value.

b) Determined by gas-phase sequencing.

c) $\mathrm{CH}_{3} \mathrm{CN}(\%, v / v)$ of solvent at the elution position in rechromatography. 


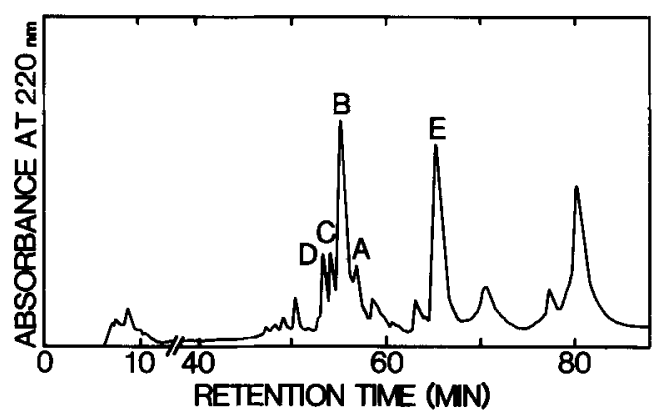

Figure 8. RP-HPLC of medium-length CNBr-fragments from $\beta$-amylase 4 . See text, Table III, and section 2.2.5 for details.

$\mathrm{NH}_{2}$-terminal Ile467 (Figure 7) was fractionated by RP-HPLC (Figure 8); peaks A to $\mathrm{D}$ were rechromatographed and subjected to $\mathrm{NH}_{2}$-terminal sequencing and amino acid analyses (Table III and Figure 7). Results indicated that the dominant peak B (Figure 8) contained Ile467-Hse494 while incomplete CNBr-cleavage after Met494 was reflected by Ile467-Gly495 and Ile467-Gln497 eluting in C and D, respectively. Peak A contained Ile467-Gly493. It cannot be concluded whether Ile467-Hse494 represents a major $\mathrm{COOH}$-terminal fragment or if it is a product of $\mathrm{CNBr}$-cleavage at Met494, since even free methionine is easily converted by $\mathrm{CNBr}$ to homoserine lactone (15). However, on a molar basis the fragments in $A$ to $D$ represent approx. $95 \%$ of what was anticipated for a CNBr-fragment based on the yield of Leul6Hse49 originating from the $\mathrm{NH}_{2}$-terminal region (peak E, Figure 8). Therefore, we conclude that the formation of $\beta$-amylase 4 results from proteolysis of different bonds in the sequence Gly492-Ala498 (Figure 7). RP-HPLC purification (data not shown) of very short peptides from the $\mathrm{CNBr}$-cleavage yielded the fragment Gly-Gly-Gln (identified from amino acid composition and sequencing) which is compatible with the version of $\beta$-amylase 4 terminating by Gln497.

Among the separated very short fragments $\mathrm{NH}_{2}$-terminally blocked homoserine was also identified which confirms that $\beta$-amylase 4 starts at the position corresponding to the 5' end of the open reading frame (25). Electron impact mass spectrometry (data not shown) of the blocked homoserine after permethylation gave peaks at $\mathrm{m} / \mathrm{z} 161$ and 143 corresponding to the molecular ion of $\mathrm{N}$-acetyl-homoserine and $\mathrm{N}$-acetyl-homoserine lactone, respectively. The spectra further contained an intense fragment ion of $\mathrm{m} / \mathrm{z}$ 84 corresponding to the lactone ring. The occurrence of a penultimate Glu residue in the barley $\beta$-amylase $\mathrm{NH}_{2}$-terminal sequence (25) is consistent with previous observations on proteins terminating by $\mathrm{N}$-acetyl-methionine (11).

\subsection{Limited proteolysis}

Examples of the conversion of $\beta$-amylase 1 to the other main forms by various proteases (thiol, serine, aspartate, and metallo proteases) are demonstrated by analytical isoelectric focusing (Figure 9; Table IV). Four of the exogenous proteases tested generated $\beta$-amylase 4' (Table IV). However, in other cases $\beta$-amylases appeared with pI similar to forms 2 and 3 , reflecting a protease-dependent degradation of the $\mathrm{COOH}$-terminal region. A vigorous subtilisin treatment of $\beta$-amylase 1 generated an enzymatically active species $(\beta$-amylase 5 ,, $\mathrm{pI} \sim 6.0)$ with a $\mathrm{pI}$ higher than the other forms (Figure 9). In fact, from the crude extract a minor $\beta$-amylase component of a similar pI was detected by activity staining (Figure 4B, lane 1). Barley malt carboxypeptidase II and two aspartate proteases had no detectable effect on the conversions.

In order to determine the molecular size of the proteolytically generated $\beta$-amylase form, the protein bands were cut from the isoelectric focusing gel and run on SDS-PAGE. As anticipated the $\beta$-amylase 4' (from subtilisin treated $\beta$-amylase 1) showed a molecular size indistinguishable from $\beta$-amylase 4 , while $\beta$-amylase 5 ' was slightly smaller with $M_{r} \sim 53,500$ (data not shown). $\beta$-Amylase 4' generated from trypsin treated $\beta$-amylase 1 (34) had $\mathrm{pI} \sim 5.7$ and $\mathrm{M}_{\mathrm{r}}$ $\sim 55,000$ (data not shown) which is consistent with loss of three negative charges due to cleavage after Lys510 (Figure 7).

Incubation of $\beta$-amylase 1 with protease containing extract of barley malt resulted in $\beta$-amylase 4' (Figure 9A, lane 7). With less malt extract larger amounts of $\beta$-amylase 2' and 3' were 

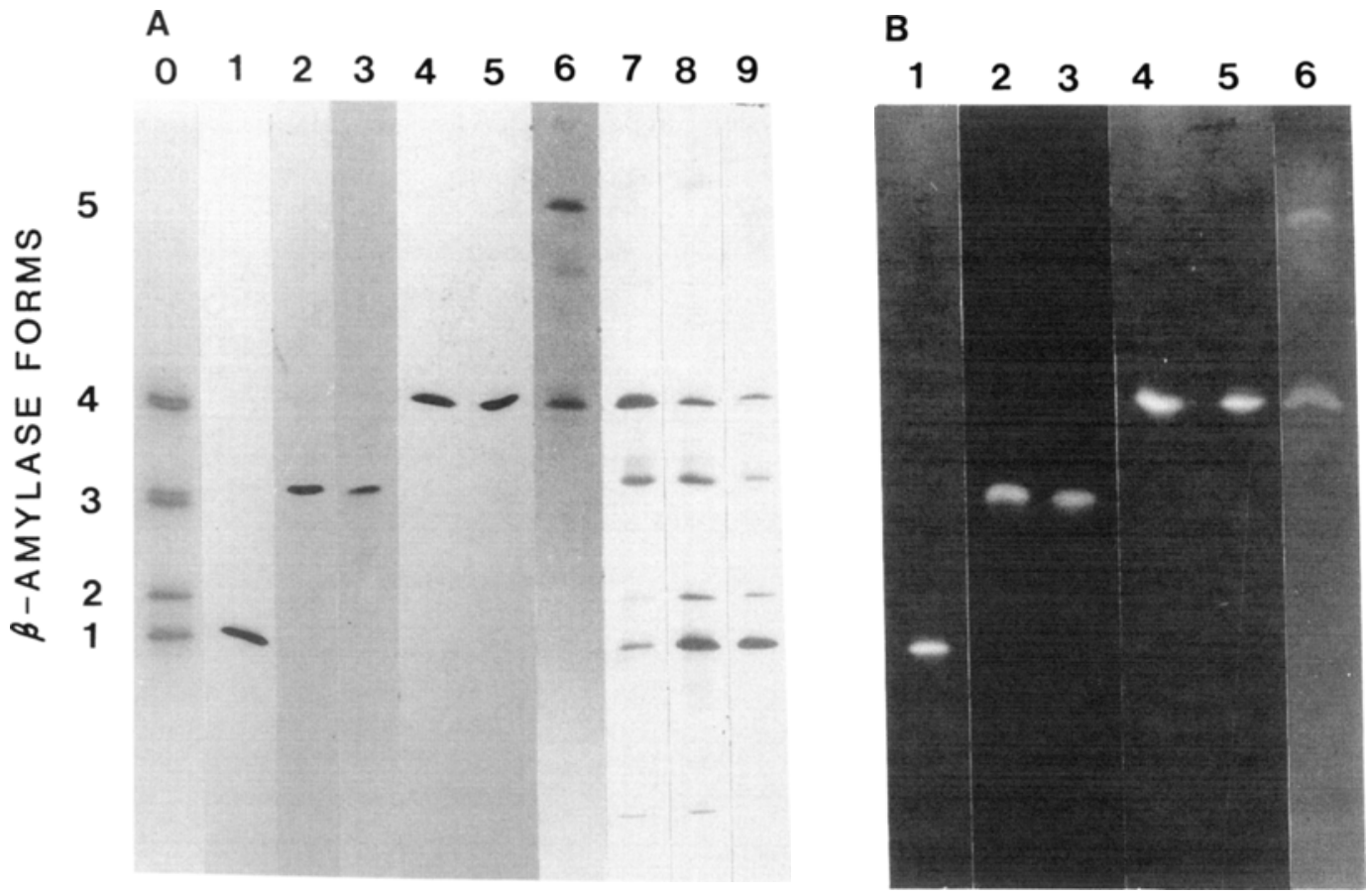

Figure 9. Isoelectric focusing of different forms of $\beta$-amylase generated by limited proteolysis of $\beta$-amylase 1 (see section 2.2.6). A. (Coomassie stain) Mixture of the purified forms of $\beta$-amylase (lane 0 ); $\beta$-amylase 1 (control, lane 1) incubated with $\alpha$-chymotrypsin (lane 2); thermolysin (lane 3); papain (lane 4); subtilisin (lane 5); subtilisin incubated for $4 \mathrm{~h}$ at $34^{\circ} \mathrm{C}$ (lane 6); malt extract (lane 7); malt extract diluted 10-fold (lane 8); malt extract preincubated with leupeptin ( $1 \mathrm{mM})$ and EDTA $(40 \mathrm{~mm})$ (lane 9). B. Same samples as in A, lanes 1 to 6, respectively, diluted and stained for amylase activity (see section 2.2 .6 ).

observed (Figure 9A, lane 8) suggesting that they are transient intermediates. A similar conversion occurred at $\mathrm{pH} 8.0$ (20 mM-Tris), although to a smaller extent than at $\mathrm{pH} 4.5$. To characterize the malt protease(s) responsible for the limited proteolysis, pepstatin A ( $1 \mathrm{mM})$, DFP (1 mM), $\operatorname{PMSF}(5 \mathrm{mM})$, and EDTA (40 mM) were included alone or in combination in the incubations (see 2.2.6). Conversion of $\beta$-amylase 1 was prevented only when leupeptin and EDTA were used in combination (Figure 9A, lane 9). Although DTNB (10 mM) and iodoacetamide (10 $\mathrm{mM}$ ) destroyed the ability of malt extracts to digest Azocoll such pretreatments failed to hinder the $\beta$-amylase processing even in the presence of EDTA $(40 \mathrm{~mm})$. The thiol protease inhibitors $\mathrm{Hg}^{2+}(1 \mathrm{mM})$, p-CMB $(0.2 \mathrm{mM})$ and
Table IV. Generation of different forms of $\boldsymbol{\beta}$-amylase by incubation of $\beta$-amylase 1 with proteases.

\begin{tabular}{ll}
\hline Protease & $\begin{array}{l}\beta \text {-Amylase } \\
\text { obtained }\end{array}$ \\
\hline Papain & 4, \\
Trypsin & 4, \\
Subtilisin A & 4, \\
Collagenase (bacterial) & 4, \\
$\alpha$-Chymotrypsin & 3 \\
Thermolysin & 3 \\
Pepsin & 1 \\
Yeast acid protease & 1 \\
Barley malt carboxypeptidase II & 1 \\
Control (no protease added) & 1
\end{tabular}

The $\beta$-amylase generated was identified by analytical isoelectric focusing (Figure 9). The numbers refer to the forms 1 to 4 isolated from barley flour. 
$\mathrm{KBrO}_{3}(2 \mathrm{mM})$ could not be used because they distorted the isoelectrofocusing pattern of the thiol containing $\beta$-amylase. The thiol protease, considered to be inhibited by leupeptin $(17,24$, 39) accounts for the majority of endopeptidase activity in malt, however, metallo- and aspartate proteinases as well as several exopeptidases are also present $(10,39)$. The lack of effect of pretreatment with DTNB and iodoacetamide suggests a role in the conversion of $\beta$-amylase for proteases other than or in addition to thiol protease.

\subsection{Adsorption to starch granules}

Both partially digested and raw barley starch granules were used for binding studies with the purified $\beta$-amylases (see section 2.2.7). Under conditions $\left(\mathrm{pH} 5.5,5^{\circ} \mathrm{C}\right.$ ) where 35 and $50 \%$ of $\alpha$-amylase adsorbed to raw and partially digested granules, respectively, none of the four $\beta$-amylase forms bound. These results confirm previous experiments employing mixtures of $\beta$-amylase forms $(9,54)$.

\section{DISCUSSION}

In the present study the purification of four charge homogeneous forms of barley $\beta$-amylase on a preparative scale was made possible by presence of high thiol concentration through the whole procedure and by ion exchange chromatography on DEAE-Fractogel. SDS-PAGE revealed small size differences between the forms. The stepwise decrease in $M_{r}$ between $\beta$-amylases 1 and 4 is consistent with the previously reported limited proteolysis in the $\mathrm{COOH}$ terminal region of $\beta$-amylase 1 (34). Much wider ranges of size differences of cereal $\beta$-amylases reported by other investigators are most likely due to intermolecular disulfide formation (42, 43).

Both in vitro limited proteolysis (34) and agreement between protein and DNA sequence analysis for $\beta$-amylase 1 (25) suggest that the isolated multiple forms are products of a single gene. This is in contrast to the high and low pI groups of soybean $\beta$-amylases that also differ in size but are encoded by two codominant alleles $(21,41)$. Recently, a B. polymyxa $\beta$-amylase
cDNA sequence was reported and in this organism active forms of the enzyme much smaller than corresponding to the full-length reading frame were generated by limited proteolysis ( 23 , 45).

A physiological function for the multiple forms of barley $\beta$-amylase has not been elucidated. The close similarity of $\mathrm{K}_{\mathrm{m}}, \mathrm{V}_{\text {max }}$, and $\mathrm{pH}$ profile determined for each of the $\beta$-amylases suggests that they possess essentially the same ability to hydrolyse soluble starch. In the case of mold glucoamylase a $\mathrm{COOH}$-terminal region that can be removed by limited proteolysis is known to confer binding to starch granules $(50$, 52 ); however, adsorption studies on native or partially digested granules failed to demonstrate raw starch binding capacity for any of the barley $\beta$-amylase forms.

The $\mathrm{COOH}$-terminal region of barley $\beta$-amylase (25) is particularly rich in glycine and glutamine/glutamic acid residues and the large differences in contents of these amino acids between $\beta$-amylases 1 and 4 agree with proteolysis occurring in this region. In contrast, the number of tyrosine, histidine, arginine and tryptophan residues remains constant in all forms reflecting the absence of these residues in the $\mathrm{COOH}$-terminal region. The estimated cysteine content of 6 and 5 residues for $\beta$-amylases 1 and 4 , respectively, is higher than the reported values of about 4 from earlier chemical analysis (53) and 5 in the cDNA sequence (25). The difference of one sulfhydryl group between barley $\beta$-amylases 1 and 4 however, is consistent with proteolytic removal of a fragment(s) containing cysteine (Figure 7).

The smallest form, purified $\beta$-amylase 4 , occurred with $\mathrm{COOH}$-termini at three or four different positions in the sequence GlyMetGlyGlyGln 497 which is part of a conserved 11 residue-sequence that is repeated 4 times in the COOH-terminal region (25) (Figure 7). The largest form, $\beta$-amylase 1 terminates at Ala533 (34) and the experimentally determined size and charge differences between the four purified forms of $\beta$-amylase could be explained from proteolysis in the four repeat regions. The intermediate $\beta$-amylase forms $3^{1}, 3^{2}$ and 2 are thus suggested to have $\mathrm{COOH}$-termini at or near Gln508, Gln519 or Gly528 (Figure 7). 
We believe the proteolytic attack on barley $\beta$-amylase is complex and a physiological role remains to be disclosed for these events. One could speculate that the cysteine at position 503 binds to Z-protein, hence during germination release of $\beta$-amylase occurs when limited proteolysis removes the disulfide bonded $\mathrm{COOH}$-terminal region.

\section{ACKNOWLEDGEMENTS}

The authors are grateful to Dr. I. SvENDSEN for information on purification conditions for the $\mathrm{COOH}$-terminal cyanogen bromide fragments, to Dr. P. RoEPstorfF (Department of Molecular Biology, University of Odense) for mass spectrometry and to Professor M. OTTESEN for support and critical reading of the manuscript. We are indebted to Dr. M. KREIS (Rothamsted Experimental Station, Harpenden, U.K.) for information on the cDNA sequence corresponding to barley $\beta$-amylase prior to publication. Ms. BIRGITTE MARCUSSEN is acknowledged for excellent technical assistance with purification and characterization of $\beta$-amylase and peptide fragments. Mss. B. CoRnELIUSSEN, P. BREDDAM, and L. SøRENSEN are thanked for performing amino acid analysis and protein sequencing.

\section{REFERENCES}

1. BAKER, W. L. \& K. L. SMILEY: Beta-amylase su]phydryl and disulfide group reactions. Additional aspects on enzyme inhibition by ascorbic acid. J. Inst. Brew. 91, 25-30 (1985)

2. BILDERBACK.D. E.: Amylases from aleurone layers and starchy endosperm of barley seeds. Plant Physiol. 53, 480-484 (1974)

3. Briggs, D. E: Hormones and carbohydrate metabolism in germinating cereal grains. In: Biosynthesis and its Control in Plants (B. V. Milborrow, ed. ) pp. 219-277. Academic Press, London and New York (1973)

4. Breddam, K., S. B. Sørensen \& M. OtTesen: Isolation of carboxypeptidase II from malted barley by affinity chromatography. Carlsberg Res. Commun. 50, 199-209 (1985)

5. Chrispeels, M.J.\& D. Boulter: Control of storage protein metabolism in the cotyledons of germinating mung beans: role of endopeptidase. Plant Physiol. 55, 1031-1037 (1975)
6. Daussant, J. \& P. Corvazier: Biosynthesis and modifications of $\alpha$ - and $\beta$-amylases in germinating wheat seeds. FEBS Lett. 7, 191-194 (1970)

7. DREYER, T., B. HALKIER, I.SVENDSEN\& M. OTTESEN: Primary structure of the aspartic proteinase A from Saccharomyces cerevisiae. Carlsberg Res. Commun. 51, 27-41 (1986)

8. Dubois, M., K. A. Gilles, J. K. Hamilton, P. A. REBERS \& F. SMITH: Colorimetric method for determination of sugar and related substances. Anal. Chem. 38, 350-356 (1956)

9. DuNN, G.: A model for starch breakdown in higher plants. Phytochem. 13, 1341-1346 (1974)

10. EnARI, T. M. \& T. SOPANEN: Mobilisation of endospermal reserves during the germination of barley. J. Inst. Brew. 92, 25-31 (1986)

11. Flinta, C., B. Persson. H. Jörnvall \& G. von HeiJNE: Sequence determinants of cytosolic N-terminal protein processing. Eur. J. Biochem. 154, 193-196 (1986)

12. Gibson, R. M. \& B. Svensson: Chemical modification of barley malt $\alpha$-amylase 2: involvement of tryptophan and tyrosine residues in enzyme activity. Carlsberg Res. Commun. 51, 295-308 (1986)

13. Gomori. G.: Preparation of buffers for use in enzyme studies. Meth. Enzymol. 1, 138-146 (1955)

14. Goodwin, T. W.. \& R. A. Morton: The spectrophotometric determination of tyrosine and tryptophan in proteins. Biochem. J. 40,628-632 (1946)

15. Gross. E.: The cyanogen bromide reaction. Meth. Enzymol. 11, 238-255 (1967)

16. HABEEB, A.F.S. A.: Reaction of protein sulphydryl groups with Ellman's reagent. Meth. Enzymol. 25 (B), 457-464 (1972)

17. Hammerton, R. W. \& T. H. D. Ho: Hormonal regulation of the development of protease and carboxypeptidase activities in barley aleurone layers. Plant Physiol. 80, 692-697 (1986)

18. Hara-Nishimura, I, M. Nishimura \& J. DausSANT: Conversion of free $\beta$-amylase to bound $\beta$-amylase on starch granules in the barley endosperm during desiccation phase of seed development. Protoplasma 134, 149-153 (1986)

19. HejgaARd, J.: Free and protein-bound $\beta$-amylase of barley grain. Characterization by two-dimensional immunoelectrophoresis. Physiol. Plant. 38, 293-299 (1976)

20. HejGaARD, J.: “Free" and “bound" $\beta$-amylase during malting of barley. Characterization by twodimensional immunoelectrophoreses. J. Inst. Brew. 84, 43-46 (1978)

21. Hildebrand. D. F. \& T. Hymowitz: The $S p_{1}$ locus in soybean codes for $\beta$-amylase. Crop Sci. 20 , $165-168(1980)$ 
22. HIRS. C. H. W.: Determination of cystine as cysteic acid. Meth. Enzymol. 11, 59-62 (1967)

23. Kawazu, T.. Y. Nakanishi. N. Uozumi, T. SaSaki, H Yamagata, N. Tsukagoshi \& S Udaka: Cloning and nucleotide sequence of the gene coding for enzymatically active fragments of the Bacillus polymyxa $\beta$-amylase. J. Bacteriol. 169, 1564-1570 (1987)

24. Koenler. S. \& T. D. Ho: Purification and partial charcterization of a major gibberellic acid-induced protease from barley seeds. Plant Physiol. Supplement 83, abstract 154 (1987)

25. Kreis. M.. M. Williamson. B. Buxton, J. Pywell. J. HejgaARd \& I SvendSEn: Primary structure and differential expressio's of $\beta$-amylase in normal and mutant barleys. Eu : J. Biochem. in press (1987)

26. KRUGER.J. E.: Modification of wheat $\beta$-amylase by proteolytic enzymes. Cereal Chem. 56, 298-302 (1979)

27. LAEMmLi, U. K.: Cleavage of structural proteins during assembly of the head of bacteriophage T4. Nature 277, 680-685 (1970)

28. LaBerge, D. E. \& B. A. MarChylo: Heterogeneity of the beta-amylase enzymes of barley. J. Am. Soc. Brew. Chem. 41, 120-124 (1983)

29. LaBerge. D. E. \& B. A. Marchylo: Changes in beta-amylase enzymes during kernel development of barley and the effect of papain as an extractant. J. Am. Soc. Brew. Chem. 44, 16-19 (1986)

30. LaBerge. D. E. \& W. O. S. Meredith: The chromatographic properties of barley and malt $\beta$-amylase. J. Inst. Brew 75, 19-25 (1969)

31. LaBerge, D. E. \& W. O. S. Meredith: The $\beta$-amylase enzymes of barley and malt I. Purification of the malt enzymes. J. Inst. Brew. 77, 436-442 (1971)

32. Laujriere, C.. M. Lauriere \& J. Daussant: Immunohistochemical localization of $\beta$-amylase in resting barley seeds. Physiol. Plant. 67, 383-388 (1986)

33. LiNDERstrøm-LANG. K. \& C. ENGEL: Beiträge zur enzymatischen Histochemie XXIII. Uber die Verteilung der Amylase in den äusseren Schichten des Gerstenkornes. Compt. Rend. Trav. Lab. Carlsberg 21(17), 243-258 (1938)

34. LUNDGARD, R. \& B. SVENSSON: Limited proteolysis in the carboxy-terminal region of barley $\beta$-amylase. Carlsberg Res. Commun. 51, 487-491 (1986)

35. MACGREGor. A. W.: Isolation of large and small granules of barley starch and a study of factors influencing the adsorption of barley malt $\alpha$-amylase by these granules. Cereal Chem. 56, 430-434 (1979)

36. Maeda, I., S. Kiribuchi \& M. Nakamura: Digestion of barley starch granules by the combined action of $\alpha$ - and $\beta$-amylases purified from barley and barley maht. Agric. Biol. Chem. 42, 259-267 (1978)

37. Means. G. E. \& R. E. Feeney: Chemical Modification of Proteins. Holden-Day Inc., San Francisco (1971)

38. MiKami, B. \& Y. MoRITA: Location of SH groups along the polypeptide chain of soybean $\beta$-amylase. J. Biochem. 93, 777-786 (1983)

39. MIKOLA, J.: Proteinases, peptidases, and inhibitors of endogenous proteinases in germinating seeds. In: Seed Proteins. Ann. Proc. Phytochem. Soc. Eur. (J. Daussant, J. Mossé, J. Vaughan, eds. ) 20, 35-52 (1983)

40. Morita. Y., F. YaGl, S. Aibara \& H. Yamashita: Chemical composition and properties of soybean $\beta$-amylase. J. Biochem. 79, 591 -603 (1976)

41. Nakamura, I. \& Y. Futsumara: Relationship among three electrophoretic characteristics of $\beta$ amylase in soybean and wild soybean seeds. Japan. J. Breed. 35, 153-159 (1985)

42. Niku.Paavola. M. L., A. Skakoun, M. Nummi \& J. DaISSANT: The polymorphism of barley $\beta$-amylase. Biochim. Biophys. Acta 322, 181-184 (1973)

43. Nummi, M.. R. Vilhunen \& T. M. ENARI: $\beta$-Amylase: I. $\beta$-amylases of different molecular size in barley and malt. Proc. 10th Congr., Eur. Brewery Convention, Stockholm, pp. 52-61. Elsevier, Amsterdam (1965)

44. OKamoto. K. \& T. AKazawa: Enzymic mechanism of starch breakdown in germinating rice seeds. 9. de novo synthesis of $\beta$-amylase. Plant Physiol. 65 , 81-84 (1980)

45. Rhodes. C. J. Strasser \& F. FriedberG: Sequence of an active fragment of $B$. polymyxa beta amylase. Nucleic Acids Res. 15, 3934 (1987)

46. RoвYt. J. F. \& W. J. WhelAN: The a-amylase. In: Starch and its Derivatives (J. Radley, ed. ) pp. 430-476. Chapman and Hall Ltd., London (1968)

47. Robyt, J. F. \& W. J. Whelan: The $\beta$-amylase. In: Starch and its Derivatives (J. Radley, ed. ) pp. 477-497. Chapman and Hall Ltd., London (1968)

48. ROWSELL, E. V. \& L. J. GOAD: Latent $\beta$-amylase of wheat: its mode of attachment to glutenin and its release. Biochem. J. 84, 73-74P (1962)

49. Svensson, B. J. Mundy, R. M. Gibson \& I. SvendSEN: Partial amino acid sequences of $\alpha$-amylase isozymes from barley malt. Carlsberg Res. Commun. 50, 15-22 (1985)

50. SVENSSON, B.. K. LARSEn \& A. GUnNARSSON: Characterization of a glucoamylase G2 from Aspergillus niger. Eur. J. Biochem. 154, 497-502 (1986)

51. TKaChUK. R. \& K. H. TiPPLES: Wheat beta-amylases II. Characterization. Cereal Chem. 43, 62-79 (1966) 
52. UedA, S.: Fungal glucoamylase and raw starch digestion. Trends Biochem. Sci. 6, 89-90 (1981)

53. VISURI, K. \& M. NummI: Purification and characterization of crystalline $\beta$-amylase from barley. Eur. J. Biochem. 28, 555-565 (1972)

54. WALKeR, G. J. \& P. M. HOPE: The action of some a-amylases on starch granules. Biochem. J. 86, 452-462 (1963)

55. Weber. K., J. R. Pringle \& M. Osborn: Measure- ment of molecular weight by electrophoresis on SDS-acrylamide gels. Meth. Enzymol. 26, 3-27 (1972)

56. WINTER, A., K. EK \& V. B. ANDERSON: Analytical electrofocusing in thin layers of polyacrylamide gel. LKB Application Note 250 (1977)

57. WRAY, W., T. BOULIKas, V. P. WRaY \& R. HANCOCK: Silver staining of proteins in polyacrylamide gels. Anal. Biochem. 118, 197-203 (1981)

Accepted by S. O. ANDERSEN 